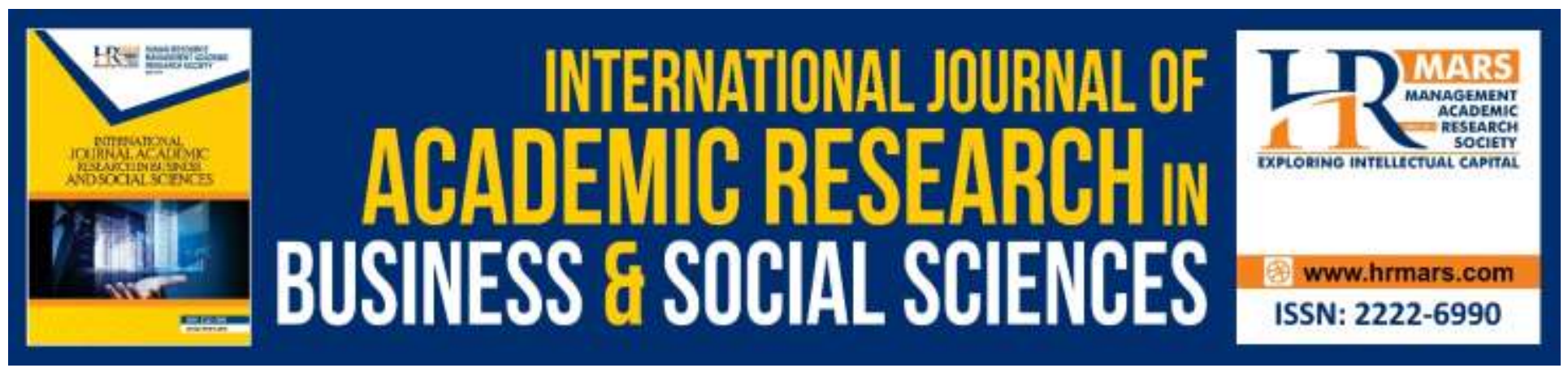

\title{
Integrating XBRL and Block Chain to Improve Corporate Transparency Integrity and Availability in Malaysia
}

\section{Zulkarnain Abd. Wahab}

To Link this Article: http://dx.doi.org/10.6007/IJARBSS/v9-i6/6081

DOI: 10.6007/IJARBSS/v9-i6/6081

Received: 18 April 2019, Revised: 12 May 2019, Accepted: 08 June 2019

Published Online: 27 June 2019

In-Text Citation: (Wahab, 2019)

To Cite this Article: Wahab, Z. A. (2019). Integrating XBRL and Block Chain to Improve Corporate Transparency Integrity and Availability in Malaysia. International Journal of Academic Research in Business and Social Sciences, 9(6), 1194-1201.

\section{Copyright: (C) 2019 The Author(s)}

Published by Human Resource Management Academic Research Society (www.hrmars.com)

This article is published under the Creative Commons Attribution (CC BY 4.0) license. Anyone may reproduce, distribute, translate and create derivative works of this article (for both commercial and non-commercial purposes), subject to full attribution to the original publication and authors. The full terms of this license may be seen

at: http://creativecommons.org/licences/by/4.0/legalcode

Vol. 9, No. 6, 2019, Pg. $1194-1201$

http://hrmars.com/index.php/pages/detail/IJARBSS

JOURNAL HOMEPAGE

Full Terms \& Conditions of access and use can be found at http://hrmars.com/index.php/pages/detail/publication-ethics 


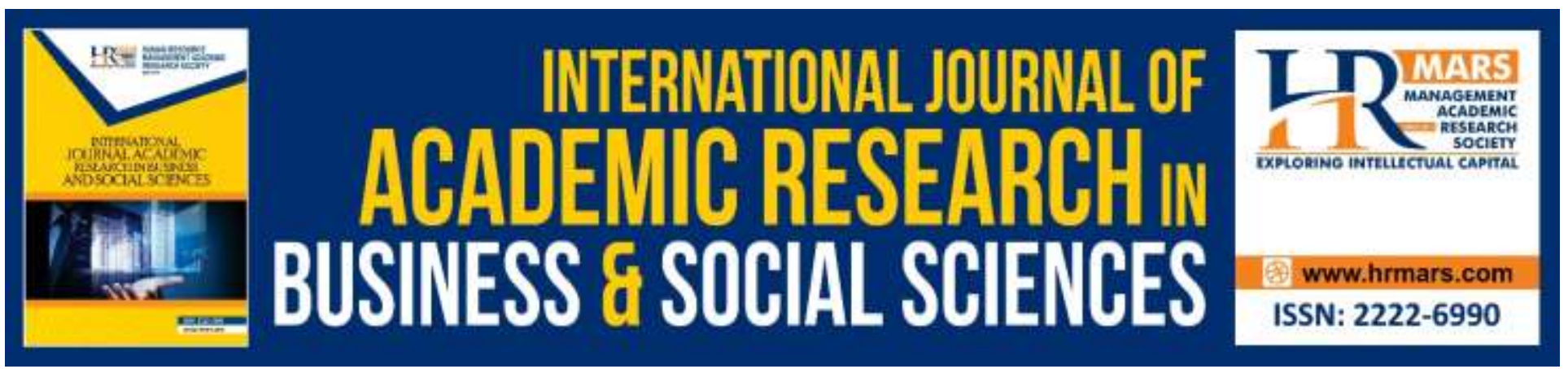

\title{
Integrating XBRL and Block Chain to Improve Corporate Transparency Integrity and Availability in Malaysia
}

\author{
Zulkarnain Abd. Wahab \\ International University Malaya Wales (IUMW), Suruhanjaya Syarikat Malaysia (SSM) \\ Malaysia
}

\begin{abstract}
Corporate Transparency is becoming more prevalence nowadays, thanks to the advancement of the Internet that provides a platform for fast dissemination of corporate good standing. The corporate good standing is a public domain record that contributes to business decision making as well as input for national economic narration. However, as the data is freely distributed online, it is prone to unauthorized alteration or illegitimate manipulation. With recent innovation of Extensible Business Reporting Language (XBRL) and Blockchain technology, public domain information such as corporate standing can now be protected from illegal changes, maintaining the integrity and availability of such information online. The challenge is how to ensure the distribution of XBRL content to a decentralized peer-to-peer network while maintaining the authority of the government towards the whole data. This paper aims to explore the suitability of integrating XBRL and blockchain technology within the Malaysian context.
\end{abstract}

Keywords: XBRL, Blockchain, Distributed Ledger, Meta-data, Corporate Standing.

\section{Introduction}

The conception of blockchain in the accounting industry may amplify the effect of technology disruption in the current financial reporting process. Although the industry may have lost its excitement towards the expected advancement of technology through a predecessor technology promoted decades ago called XBRL, some industry players are still optimistic towards the automated self-reconciliation concept brought along by blockchain technology evolution (Drew, 2017). Industry Players like PwC, Deloitte, EY, and KPMG are at the frontline of venturing into the technology (Karajovic, Kim, \& Laskowski, 2019). For example, Microsoft is partnering with KPMG in providing Blockchain as a Service (BaaS) to extend the features to the mass public.

The blockchain is a technology that allows append-only data which replicates the records between participants, creating a new architecture of a distributed system, where consensual shared state for the distributed transactional records are established across an extensive network of agnostic 
INTERNATIONAL JOURNAL OF ACADEMIC RESEARCH IN BUSINESS AND SOCIAL SCIENCES Vol. 9, No. 6, June, 2019, E-ISSN: 2222-6990 @ 2019 HRMARS

peer-to-peer (P2P), (Lo, Xu, Chiam, \& Lu, 2018). Extensible Business Reporting Language (XBRL), on the other hand, is an XML base corporate business reporting standard, with a unique feature of metadata called taxonomy extension to allow additional information which was not initially provided by the base taxonomy. This reporting standard is internationally accepted as structured documents or data presented online (Wu \& Vasarhelyi, 2004). Based on an initial study by Beerbaum (2018), XBRL and Blockchain can form symbionts product as XBRL provides high-quality structured data which is pre-requisite for machine-readable blockchain. Thus, the future for an integrated XBRL Blockchain, generally is promising and expected to revolutionist the financial sector. Malaysia, through Suruhanjaya Syarikat Malaysia (SSM), has recently implemented XBRL via mandatory online submission of Annual Returns and Financial Statements. The new Malaysian XBRL system is called Malaysian Business Reporting System (MBRS). The compulsory implementation is, however, creates a considerable hype in Malaysian financial practitioner (NST, 2018). While XBRL has been gaining its popularity due to the mandatory implementation, Blockchain is also the topic in town, and still gaining its momentum. This can be seen through the recent significant increase in interest on Blockchain and XBRL keyword reported by Google Search trend in Malaysia in recent years as illustrated in Figure 1 below;

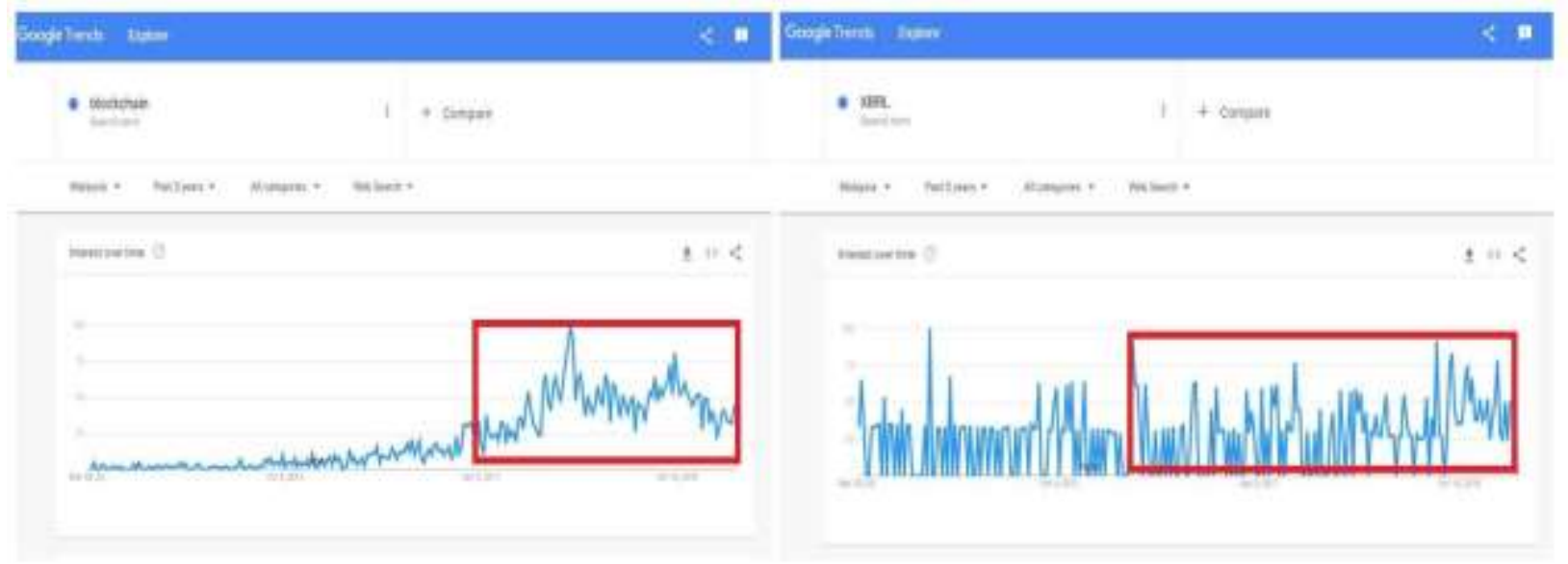

Figure 1-Google Search Trend for Blockchain \& XBRL keyword in Malaysia for the past 5 years Since the interest shown in recent years for the topics indicates that a study is relevant to be carried out.

In one side, the topic of integrating Blockchain and XBRL is still new, as most researchers are focusing on the research topic separately (Beerbaum, 2018). On the other hand, the increase in demand for Corporate Transparency had triggered the integration of the two technology to provide higher integrity and availability.

The enthusiasm for blockchain adoption is not without any reservation. Based on the study by Oh \& Shong, (2017) few issues have been identified as the challenges to implementation of blockchain in financial information. They are;

i) Peer to Peer concept (P2P) - Inability to identify a single responsibility party due to collaborative ownership of the information. 
INTERNATIONAL JOURNAL OF ACADEMIC RESEARCH IN BUSINESS AND SOCIAL SCIENCES Vol. 9, No. 6, June, 2019, E-ISSN: 2222-6990 @ 2019 HRMARS

ii) Scalability - Capacity of data may be limited as compared to actual financial reports capacity requirements

iii) Transparency - Privacy and pseudo-anonymity maybe disrupted due to open traceability of transaction.

iv) Security - Difficulties in information recoveries in the case of security compromise as the private key is irrecoverable if lost or hacked.

v) System Stability - Since data is not located in a single repository, the control over computing capacity and resources could become an issue. Difficulties in handling large volume over multiple environments can contribute to performance and stability issue.

\section{Discussing the convergence}

Based on a literature study by Beerbaum, (2018) the topic that combines XBRL and Blockchain is scarcely discussed in academic journal due to the very early stage of technology development. Most of the study promotes the convergence of the two technology due to few aspects; 1 ) non-reliance to single authoritative party for verification but via P2P interlocking system (Deloitte \& Touche Wirtschaftsprüfungsgesellschaft, 2016); 2) speed for processing, due to a large number of P2P network processing resources with most of the processes are automated (Beerbaum, 2018). In contrary, Oh \& Shong (2017) reveal more aspects contributes to the motive of the convergence such as; 3) Scalability; 4) Transparency; 5) Information Security and Data Integrity; and 6) System stability and availability. Oh \& Shong (2017) also have identified that blockchain can be categorized into three types;

1) Public Blockchain, fully open access with almost no governance ownership;

2) Consortium Blockchain - governed by a group of trusted parties; and

3) Private Blockchain - fully governed by an authority to serve a specific purpose.

Typically, the segregation is based on the level of control over the blockchain network in which, to serve the requirement of Public Authority and governance body. The issue of governance had also being raised by European financial practitioner as reported by Colgren, (2018), leading to the formation of European Financial Transparency Gateway (EFTG), experimenting blockchain with the whole financial life-cycle. Since the move by XBRL counterparts in the US and Europe towards convergence with blockchain technology are promising, the direction of Malaysian XBRL and blockchain convergence also seems inevitable.

XBRL implementation in Malaysia starts with the introduction of standard taxonomy by SSM. This standard taxonomy is called SSM Taxonomy (SSMXT). This taxonomy will be used by all companies in Malaysia for submission of financial reports. This taxonomy is also extensible by other jurisdictions to serve the context and purpose of the reports. Other Malaysian authorities which are actively involved in XBRL initiatives are Central Bank of Malaysia (BNM), Inland

Revenue Board (LHDN) and Securities Commission of Malaysia (SC) (Yahaya, 2018). The taxonomy and the metadata is the most crucial part in XBRL implementation. It is also the information that creates context and positioned the perspectives of the financial reports. However, it cannot not stand alone as it needs the actual information that carries the core information of the records. This 
INTERNATIONAL JOURNAL OF ACADEMIC RESEARCH IN BUSINESS AND SOCIAL SCIENCES Vol. 9, No. 6, June, 2019, E-ISSN: 2222-6990 (C) 2019 HRMARS

behaviour defined best on how a blockchain works, as it relies on information that stores in distributed ledger which verifies the integrity of the information with the chaining of other information (Lo et al., 2018).

\section{Integrating XBRL and Blockchain}

XBRL consists of 2 main information components which is XBRL instances and taxonomies (IXBRL, 2006). The $X B R L$ instances are the records that traditionally submitted to SSM via manual lodgments. The taxonomies, on the other hand, are not the statutory information which were prescribed by the companies act (Companies Act 777, 2016). By having this understanding, the taxonomies are the components of information which is very likely to be integrated with blockchain technology. Based on Figure 2, proposed integration of XBRL and Blockchain technology can be initiated by extending the taxonomies into the blockchain network.

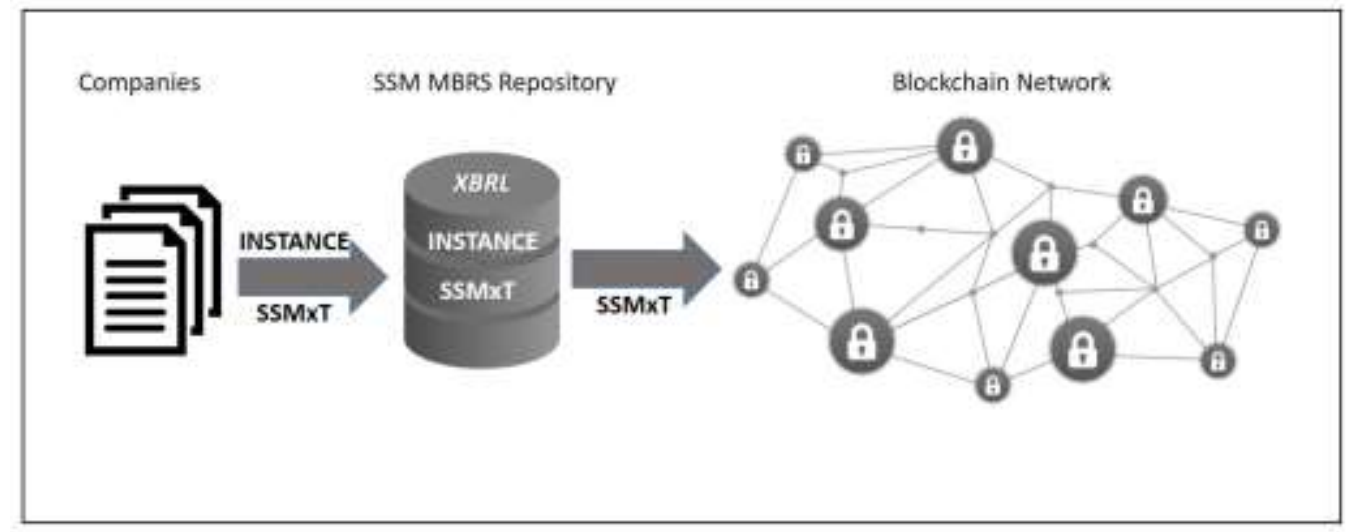

Figure 2- First phase XBRL integration to Blockchain architecture

The proposed first phase integration will enable the features of blockchain to be incorporated into XBRL implementation without the concern of relieving the control of instances information by SSM. The main Instances will still be stored within the private storage of SSM. The taxonomies will be then shared within the P2P network, establishing the interlocking mechanism directly to the taxonomies, and indirectly to the instances. The first phase will also serve as the transitional stage where the companies will later be able to participate into the blockchain P2P network which will allow better integration, with the industry.

The eventual integration of XBRL will allow faster and secured integration and especially if the type of blockchain infrastructure adopted is Consortium or Private Blockchain network.

The proposed final XBRL and Blockchain integration is as depicted in Figure 3 below; 
INTERNATIONAL JOURNAL OF ACADEMIC RESEARCH IN BUSINESS AND SOCIAL SCIENCES Vol. 9, No. 6, June, 2019, E-ISSN: 2222-6990 @ 2019 HRMARS

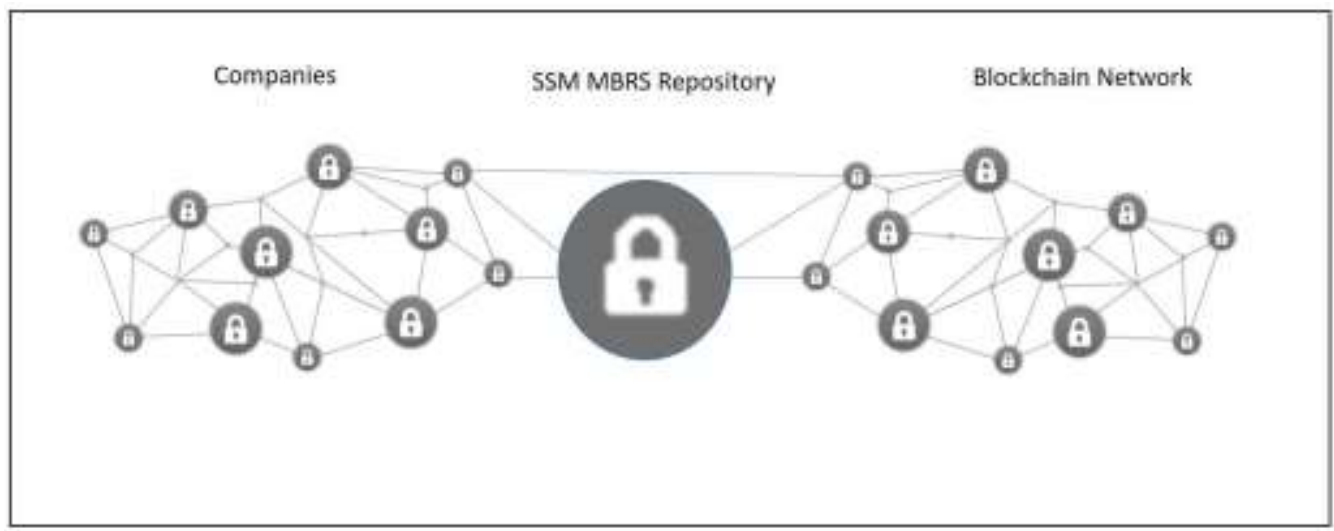

Figure 3- Proposed Final integration architecture

\section{Assessment Method}

Since this study will be exploratory research on the possibility of the integration of XBRL/MBRS and Blockchain, this case study will adopt the Suitability Evaluation Framework by Lo et al. (2018), which was used to evaluate Australian Government systems.

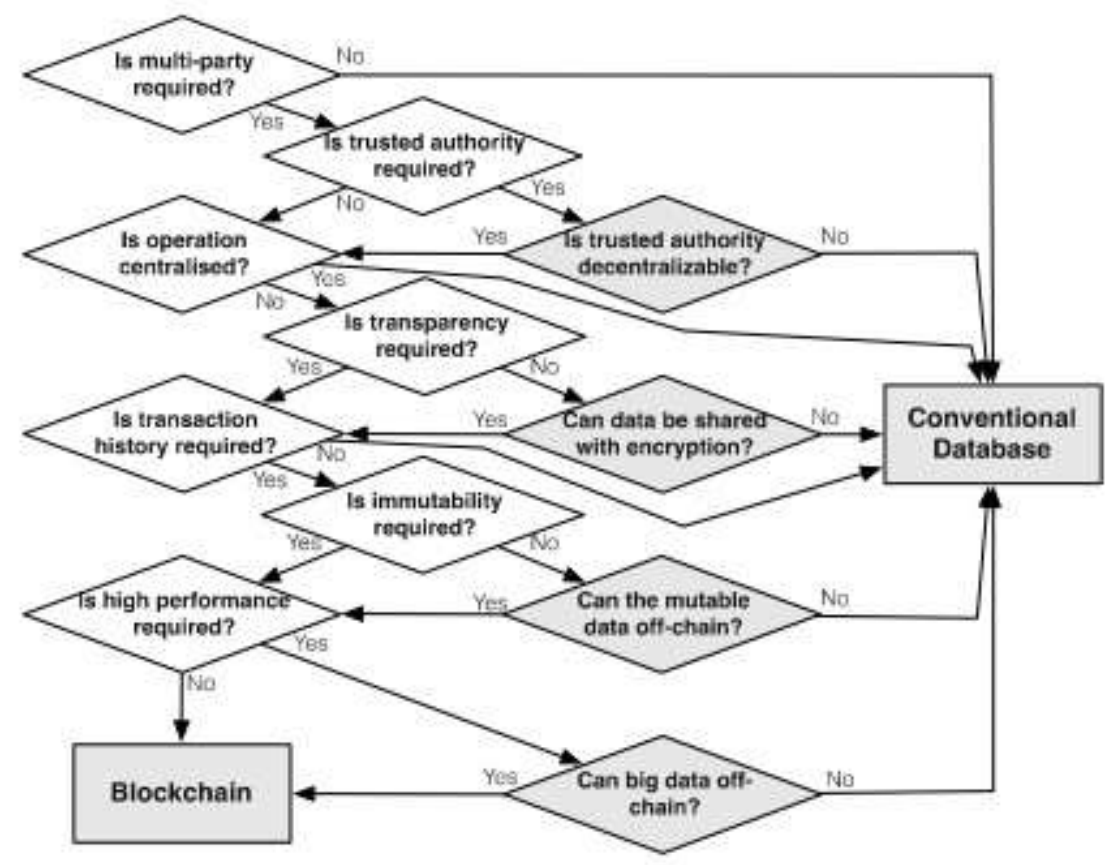

Figure 4 -Suitability evaluation framework (Lo, et al. 2018) 
Table 1: Result of Suitability Evaluation

\begin{tabular}{|c|c|c|}
\hline A & Multi-party & Required / Not Required \\
\hline B & Trusted authority & Required / Not Required \\
\hline C & Centralized Operation & Required / Not Required \\
\hline D & $\begin{array}{l}\text { Data Transparency vs } \\
\text { confidentiality }\end{array}$ & Transparent / Confidential \\
\hline$E$ & Data Integrity & Required / Not Required \\
\hline $\mathrm{F}$ & Data Immutability & Required / Not Required \\
\hline \multirow[t]{2}{*}{ G } & High Performance & Required / Not Required \\
\hline & Result & $\begin{array}{l}\text { Blockchain/Conventional } \\
\text { Database }\end{array}$ \\
\hline
\end{tabular}

\section{Conclusion}

The current implementation of XBRL in Malaysia is still in its infancy stage. The only XBRL implementation is currently using conventional database approach. This study will explore using a case study on the current implementation of XBRL in Suruhanjaya Syarikat Malaysia, whether the non-functional requirement proposed are fully suitable from the perspective of stakeholders as well as the implementers. The focus of this study, however, concentrates on the initial practicality of the integration. There are rooms to further investigate the implications of the integration towards multiple industries as well as the stakeholders.

\section{Acknowledgement}

I'm extending my special thanks to Faculty of Science, Technology, Engineering and Mathematics, IUMW, Companies Commission of Malaysia (SSM) and Kaizentrenovation Sdn. Bhd. for the guidance and contribution for this publication.

\section{Corresponding Author}

Zulkarnain bin Abd Wahab, International University of Malaya Wales (IUMW), Companies Commission of Malaysia (SSM),

Malaysia,

Email: zulkarnain@ssm.gov.my,

\section{References}

\section{Journal Article}

Beerbaum, D. (2018). Blockchain A Business Case for XBRL: A Beast or a Lame Duck? SSRN Electronic Journal, 1-9. https://doi.org/10.2139/ssrn.3174431 
INTERNATIONAL JOURNAL OF ACADEMIC RESEARCH IN BUSINESS AND SOCIAL SCIENCES

Vol. 9, No. 6, June, 2019, E-ISSN: 2222-6990 @ 2019 HRMARS

Colgren, T. D. (2018). XBRL, BLOCKCHAIN, AND NEW TECHNOLOGIES: A focus on innovative solutions and core competencies in technology and analytics is a must for management accountants. In Strategic Finance (p. 62).

Companies Act 777 (2016). Suruhanjaya Syarikat Malaysia. Retrieved from https://www.ssm.com.my/acts/fscommand/CompaniesAct.htm

Deloitte \& Touche Wirtschaftsprüfungsgesellschaft. (2016). Blockchain Technology A gamechanger in accounting? Deloitte. Retrieved from https://www2.deloitte.com/content/dam/Deloitte/de/Documents/Innovation/Blockchain__A game-changer in accounting.pdf

Drew, J. (2017). Real talk about artificial intelligence and blockchain. Journal of Accountancy, 1- 7.

IXBRL. (2006). Extensible Business Reporting Language (XBRL) 2.1 RECOMMENDATION - 200312-31 + Corrected Errata - 2005-11-07.

Karajovic, M., Kim, H. M., \& Laskowski, M. (2019). Thinking Outside the Block: Projected Phases of Blockchain Integration in the Accounting Industry. Australian Accounting Review, (November), 1-12. https://doi.org/10.1111/auar.12280

Lo, S. K., Xu, X., Chiam, Y. K., \& Lu, Q. (2018). Evaluating Suitability of Applying Blockchain. Proceedings of the IEEE International Conference on Engineering of Complex Computer Systems, ICECCS, 2017-Novem, 158-161. https://doi.org/10.1109/ICECCS.2017.26

Oh, J., \& Shong, I. (2017). A case study on business model innovations using Blockchain: focusing on financial institutions. Asia Pacific Journal of Innovation and Entrepreneurship, 11(3), 335-344. https://doi.org/10.1108/apjie-12-2017-038

Wu, J., \& Vasarhelyi, M. A. (2004). Business Intelligence Techniques, (April 2015). https://doi.org/10.1007/978-3-540-24700-5

\section{Online Newspaper Articles}

NST, N. A. M. (2018, September 27). Mandatory for companies to submit their documents to SSM via new platform soon. Https://Www.Nst.Com.My/News/Nation/2018/09/415468/Mandatory-CompaniesSubmitTheir-Documents-Ssm-New-Platform-Soon, pp. 9-12. Retrieved from https://www.nst.com.my/news/nation/2018/09/415468/mandatory-companies-submittheirdocuments-ssm-new-platform-soon

\section{Conference}

Yahaya, K. (2018). Session 6 Reporting in the age of Disruption : XBRL Adoption in Malaysia and Around the World. In Reporting in the Age of Disruption : XBRL Adoption in Malaysia and Around the World. 